\title{
Contribution of Pyk2 pathway and reactive oxygen species (ROS) to the anti-cancer effects of eicosapentaenoic acid (EPA) in PC3 prostate cancer cells
}

\author{
Keiichi Oono ${ }^{1}$, Kazuo Ohtake ${ }^{1}$, Chie Watanabe ${ }^{2}$, Sachiko Shiba ${ }^{1}$, Takashi Sekiya ${ }^{2}$ and Keizo Kasono ${ }^{1 *}$
}

\begin{abstract}
Background: $n-3$ polyunsaturated fatty acids ( $n-3$ PUFAs), including eicosapentaenoic acid (EPA) and docosahexaenoic acid (DHA), are thought to exert protective effects in cardiovascular diseases. In addition, n-3 PUFAs have demonstrated anti-cancer effects in vitro and in vivo.

Objective: We investigated the anti-cancer effects and mechanism of action of EPA on PC3 prostate cancer cells in vitro. Methods: PC3 cells were treated with various concentrations of EPA, and cell survival and the abilities of migration and invasion were evaluated. The time course of the growth inhibitory effect of EPA on PC3 cells was also assessed. The mechanism underlying the anti-cancer effects of EPA was investigated by human phosphokinase and human apoptosis antibody arrays, and confirmed by western blot analysis. We also examined the contribution of reactive oxygen species (ROS) to the effects of EPA using the ROS inhibitor N-acetyl cysteine.

Results: EPA decreased the survival of PC3 cells in a dose-dependent manner within $3 \mathrm{~h}$ of application, with an effective concentration of $500 \mu \mathrm{mol} / \mathrm{L}$. EPA inhibited proline-rich tyrosine kinase (Pyk) 2 and extracellular signalregulated kinase $1 / 2$ phosphorylation as determined by western blotting and the antibody arrays. The growth of PC3 cells was inhibited by EPA, which was dependent on ROS induction, while EPA inhibited Pyk2 phosphorylation independent of ROS production.
\end{abstract}

Conclusions: Inhibition of Pyk2 phosphorylation and ROS production contribute to the anticancer effects of EPA on PC3 cells.

Keywords: PC3, EPA, ROS, ERK, Pyk2

\section{Introduction}

Prostate cancer $(\mathrm{PC})$ is the second most common cancer in men worldwide, with the incidence increasing in Asian countries, including Japan [1, 2]. Standard treatments for PC include surgery, radiation, hormone therapy, and chemotherapy. Advanced PC with metastasis is treated with androgen deprivation therapy (ADT) in association with medical or surgical castration [3]. However, after several years of treatment, patients ultimately develop castration resistance; non-metastatic or

\footnotetext{
* Correspondence: kasono@josai.ac.jp

${ }^{1}$ Laboratory of Physiology, Faculty of Pharmaceutical Sciences, Josai

University, 1-1 Keyakidai, Sakado, Saitama 350-0295, Japan

Full list of author information is available at the end of the article
}

metastatic castration-resistant (CR) PC is refractory to $\mathrm{ADT}$ and develops mechanisms to proliferate irrespective of castration. Furthermore, anti-androgen therapy can worsen the patient's condition by stimulating PC growth. This has been demonstrated with flutamide therapy and is known as anti-androgen withdrawal syndrome [4]. Only a few chemotherapeutics and radiation have been developed for the treatment of CRPC [5], and these have not improved the poor prognosis of this disease [6].

There is growing evidence that $\mathrm{n}-3$ polyunsaturated fatty acids (n-3 PUFAs) found in fish oil-especially eicosapentaenoic acid (EPA) and docosahexaenoic acid (DHA)—can improve lipid metabolism and blood lipid

(c) The Author(s). 2020 Open Access This article is distributed under the terms of the Creative Commons Attribution 4.0 International License (http://creativecommons.org/licenses/by/4.0/), which permits unrestricted use, distribution, and 


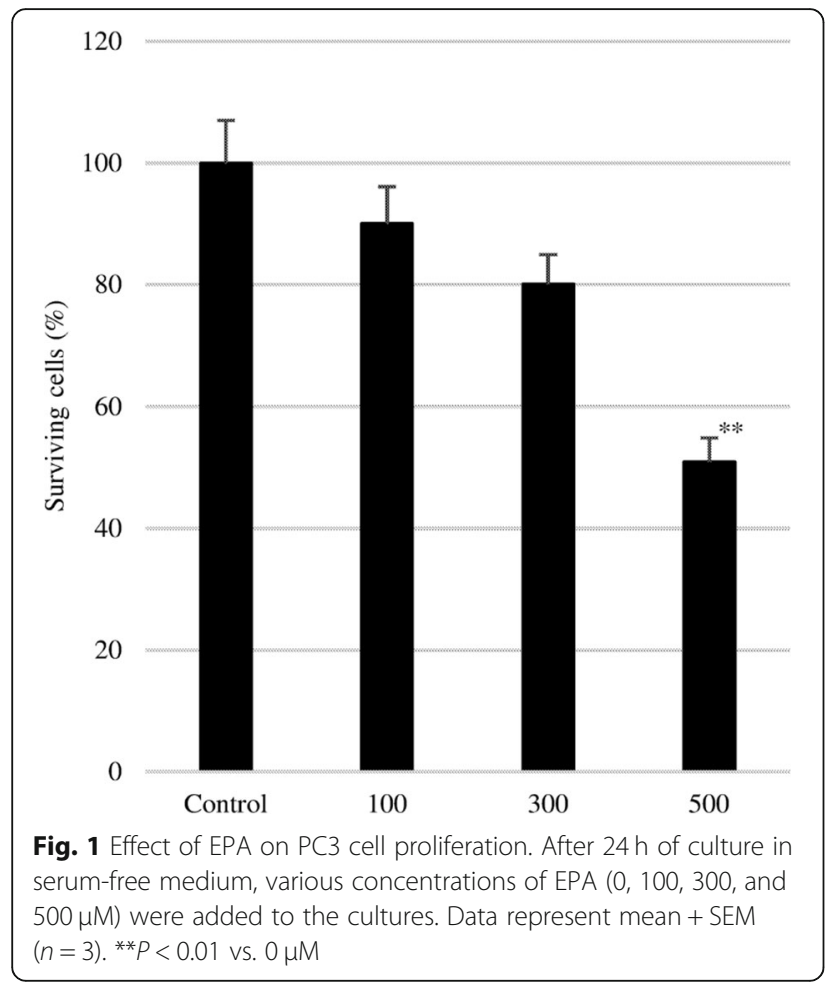

Fig. 1 Effect of EPA on PC3 cell proliferation. After $24 \mathrm{~h}$ of culture in serum-free medium, various concentrations of EPA $(0,100,300$, and $500 \mu \mathrm{M})$ were added to the cultures. Data represent mean + SEM $(n=3) .{ }^{* *} P<0.01$ vs. $0 \mu \mathrm{M}$ profiles, prevent the progression of atherosclerosis, and reduce the incidence of cardiovascular diseases [7] as well as liver and plasma triglyceride levels [8]. We previously demonstrated that chronic oral administration of EPA prevented endothelial dysfunction in a mouse model of type 2 diabetes [9]. n-3 PUFAs have also been reported to have various anti-cancer effects in several types of malignancy in vitro and in vivo. n-3 PUFAs inhibit extracellular signal-regulated kinase (ERK) and Akt signaling pathways and show anti-cancer effects in breast cancer [10], reduce the incidence of liver cancer in hepatitis virus-infected patients [11], and lower the risk of pancreatic cancer [12]. Cis-unsaturated fatty acids including EPA are easily incorporated into cancer cells and induce free radical generation, inducing tumoricidal action [13-16]. However, other studies have suggested that there is insufficient evidence for a significant association between n-3 PUFAs and cancer incidence [17].

We previously reported that EPA and DHA have anti-proliferative, -migratory, and -invasive effects in the PC3 CRPC cell line [18]. We also observed that the combination of anti-cancer drugs and n-3 PUFAs synergistically inhibited the proliferation of PC3 cells (unpublished data). However, the mechanism of action of n-3 PUFAs, and specifically, the molecular basis for the inhibitory effects of EPA on PC3 cell proliferation, migration, and invasion has yet to be defined.

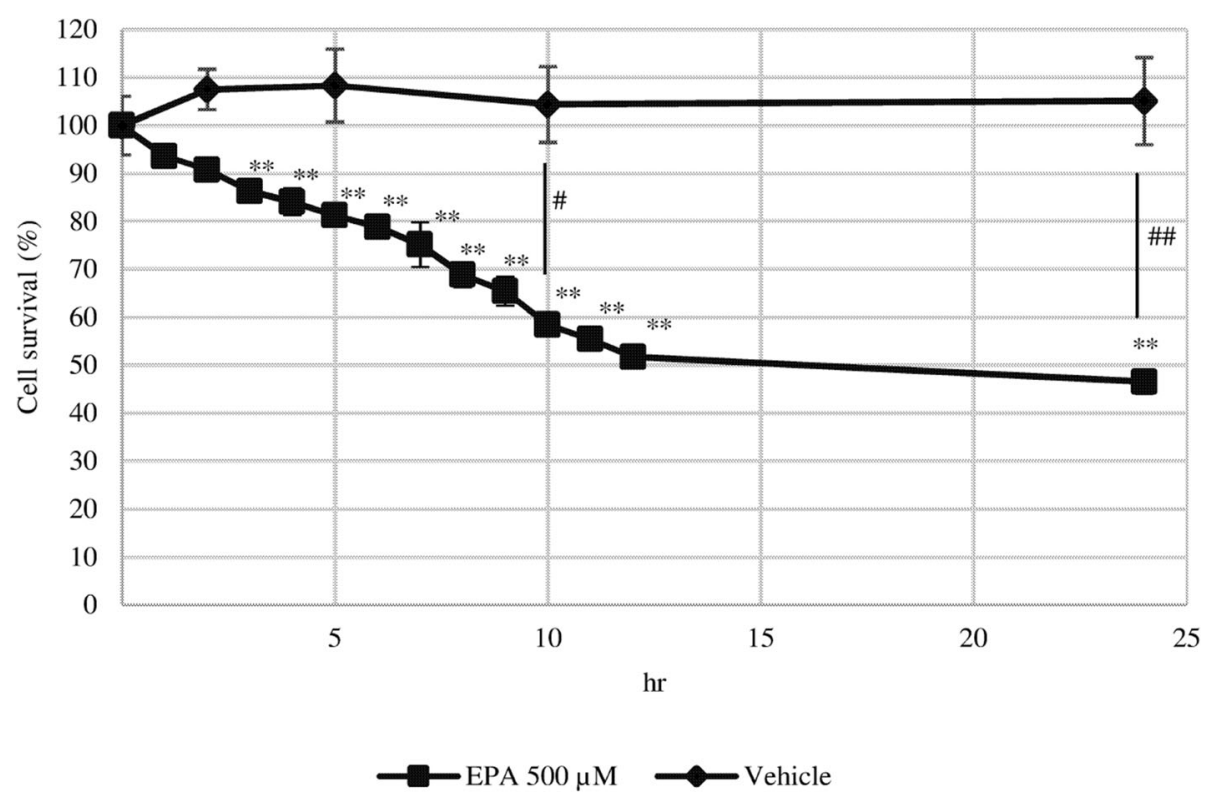

Fig. 2 Effect of EPA on the time course of PC3 cell proliferation. After $24 \mathrm{~h}$ of culture in serum-free medium, EPA (500 $\mu \mathrm{M})$, or vehicle was added to the cells. Data represent mean \pm SEM $(n=3) .{ }^{* *} P<0.001$ vs $0 h ;{ }^{\#} P<0.05,{ }^{\# \#} P<0.01$ v. vehicle 


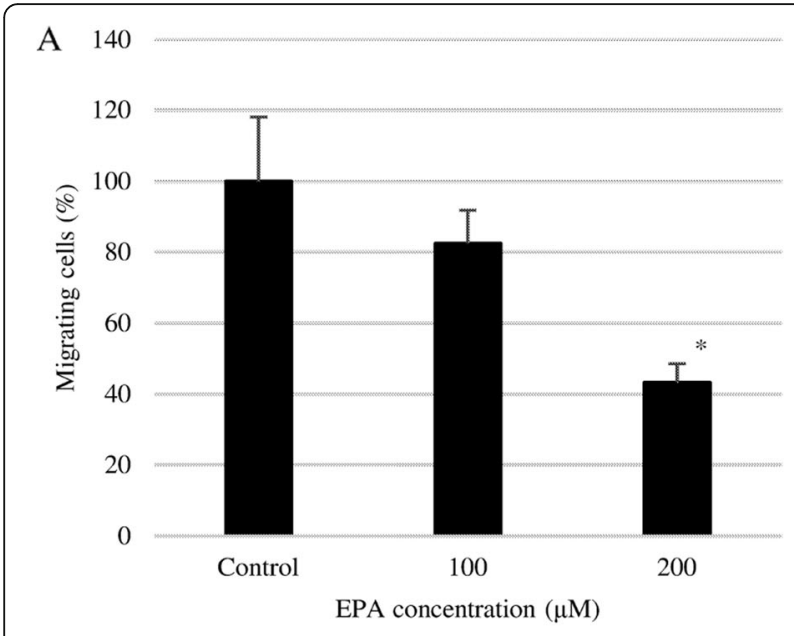

B

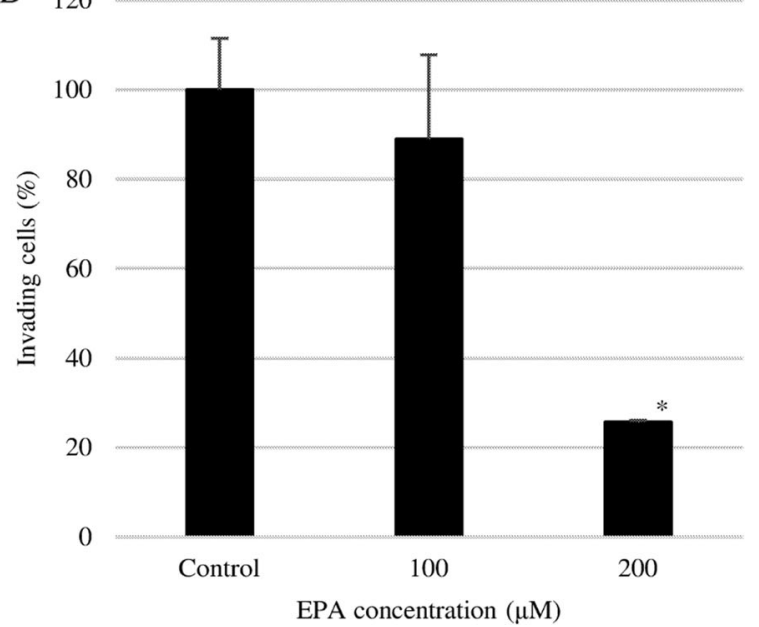

Fig. 3 Effect of EPA on EPA on PC3 (a) cell migration and (b) invasion. Double-chambered cell culture dishes with a transwell insert separating the two chambers were used to evaluate PC3 cell migration and invasion. Cells were seeded in the upper chamber, which was uncoated (migration) or coated (invasion) with Matrigel, while the lower chamber was filled with DMEM containing 10\% FBS. Data represent mean + SEM $(n=3) . * P<0.05$

Various signaling pathways control cell proliferation; their dysregulation can lead to over-proliferation and aberrant migration and invasion. Tyrosine kinase (TK) is an important mediator of cell proliferation. Receptor (R) TK is a transmembrane receptor with TK activity, whereas non-receptor (NR) TK is present in the cytoplasm and comprises $\mathrm{Abl}, \mathrm{Src}$, and prolinerich TK (Pyk)2 families. Various NRTKs are expressed in PC3 cells, and Src plays a role in multiple biological processes in PC cells [19]. Activation of these TKs leads to cell proliferation through activation of transcription factors that promote cell cycle progression.

NRTKs enhance the proliferation of cancer cells to promote their survival, so suppressing these pathways can lead to cell growth inhibition or death. Most cancer cells are resistant to apoptosis and activate pathways that suppress the pro-apoptotic active form of caspases [20]. Moderate ROS levels may cause tumorigenesis through DNA damage in protumorigenic cells [21]. Thus, eliminating or reducing ROS production is a potential strategy for cancer therapy, since ROS also regulate the activation of several RTKs and NRTKs [22]. On the other hand, EPAinduced ROS overproduction stimulates apoptotic signals in HepG2 liver cancer cells [23], and oxidative stress causes PC3 cell death by stimulating mitochondrial ROS production and apoptosis [24]. DHA has been found to cause cell death by inducing ROS production in PC3 and DU145 PC cells [25].

In the present study, we investigated the mechanism underlying the anti-cancer effects of n-3 PUFA EPA, first by characterizing the optimal concentration and time required for these effects in PC3 cells, and then by analyzing protein expression by western blotting and antibody arrays. To clarify the effects of ROS production induced by EPA, we used the ROS inhibitor N-acetyl cysteine (NAC).

\section{Materials and methods Reagents}

EPA (Sigma-Aldrich, St. Louis, MO, USA) was dissolved in 99\% isopropanol (Wako, Tokyo, Japan) and stored at $-30{ }^{\circ} \mathrm{C}$. For experiments, EPA was dissolved in serum-free Dulbecco's modified Eagle's medium (DMEM; Gibco, New York, NY, USA) containing 3\% bovine serum albumin (BSA) (Sigma-Aldrich), and NAC (Wako) was dissolved in phosphate-buffered saline (PBS). Human phospho-kinase array (R\&D Systems, Minnesota, MN, USA) and the human apoptosis antibody Array Membranes (Abcam, Cambridge, UK) were used for protein analysis. Antibodies against ERK1/2, phosphorylated (p)-ERK1/2, Pyk2, p-Pyk2, and $\beta$-actin were from Cell Signaling Technology Japan (Tokyo, Japan) and were diluted with Can Get Signal reagent (Toyobo, Osaka, Japan).

\section{Cell culture}

PC3 cells (Riken BRC Cell Bank, Tsukuba, Japan) were grown in DMEM (Gibco) supplemented with $10 \%$ heatinactivated fetal bovine serum (FBS), $100 \mathrm{U} / \mathrm{mL}$ of penicillin, and $100 \mu \mathrm{g} / \mathrm{mL}$ of streptomycin (Gibco). The cells were cultured at $37^{\circ} \mathrm{C}$ in a humidified $5 \% \mathrm{CO}_{2}$ atmosphere. 


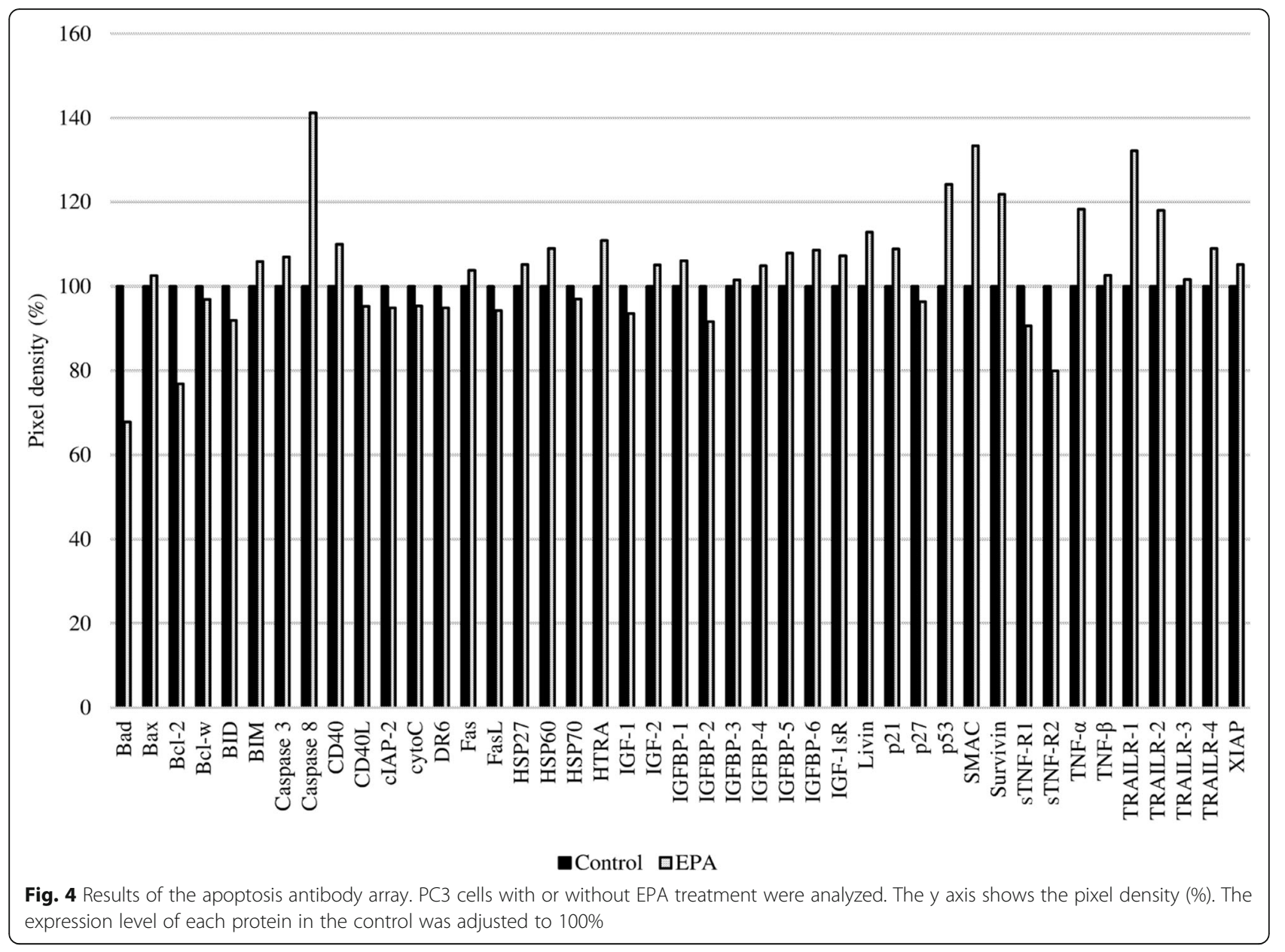

\section{Cell proliferation assay}

PC3 cells were seeded in 35-mm dishes at a density of $3 \times 10^{5}$ cells/dish in DMEM containing 10\% FBS and incubated for $24 \mathrm{~h}$, and the culture medium was replaced with serum-free DMEM after washing with PBS. After an additional $24 \mathrm{~h}$, the cells were washed with PBS, and serum-free medium containing 3\% BSA and various concentrations of EPA $(100-500 \mu \mathrm{M})$ were added. After $24 \mathrm{~h}$, the number of cells was counted with a hemocytometer.

\section{Time course of cell proliferation}

PC3 cells were seeded in a 35 -mm high $\mu$-Dish Grid500 (Ibidi, Planegg, Germany) at a density of $3 \times 10^{5}$ cells/dish in DMEM containing 10\% FBS. After $24 \mathrm{~h}$, the cells were washed with PBS, and serum-free DMEM was added; after another $24 \mathrm{~h}$, the cells were washed with PBS, and serum-free medium containing $3 \%$ BSA with or without EPA $(500 \mu \mathrm{M})$ was added. Cells were imaged with a microscope and counted at the indicated times.

\section{Migration and invasion assay}

Migration and invasion were assessed as described in our previous study [18]. Briefly, we used Transwell membranes (8- $\mu \mathrm{m}$ pore size; Corning Inc., Corning, NY, USA) with or without Matrigel coating. PC3 cells were cultured in the upper chamber of a Transwell insert in serum-free medium containing various concentrations of EPA. The lower chamber was filled with DMEM containing 10\% FBS. For the migration assay, Matrigel-uncoated upper chambers were used; cells were seeded at a density of $2 \times$ $10^{5}$ cells $/ \mathrm{mL}$, and after $24 \mathrm{~h}$, the number of cells that had migrated into the lower chamber was counted. For the invasion assay, Matrigel-coated upper chambers were used. Before seeding the cells, Matrigel was fixed by incubation for $90 \mathrm{~min}$, and cells were seeded at a density of $1 \times 10^{5}$ cells $/ \mathrm{mL}$. After $48 \mathrm{~h}$, cells that had invaded into the lower chamber were counted.

\section{Antibody arrays}

PC3 cells were cultured in DMEM containing 10\% FBS for $24 \mathrm{~h}$, then cultured in serum-free medium for 


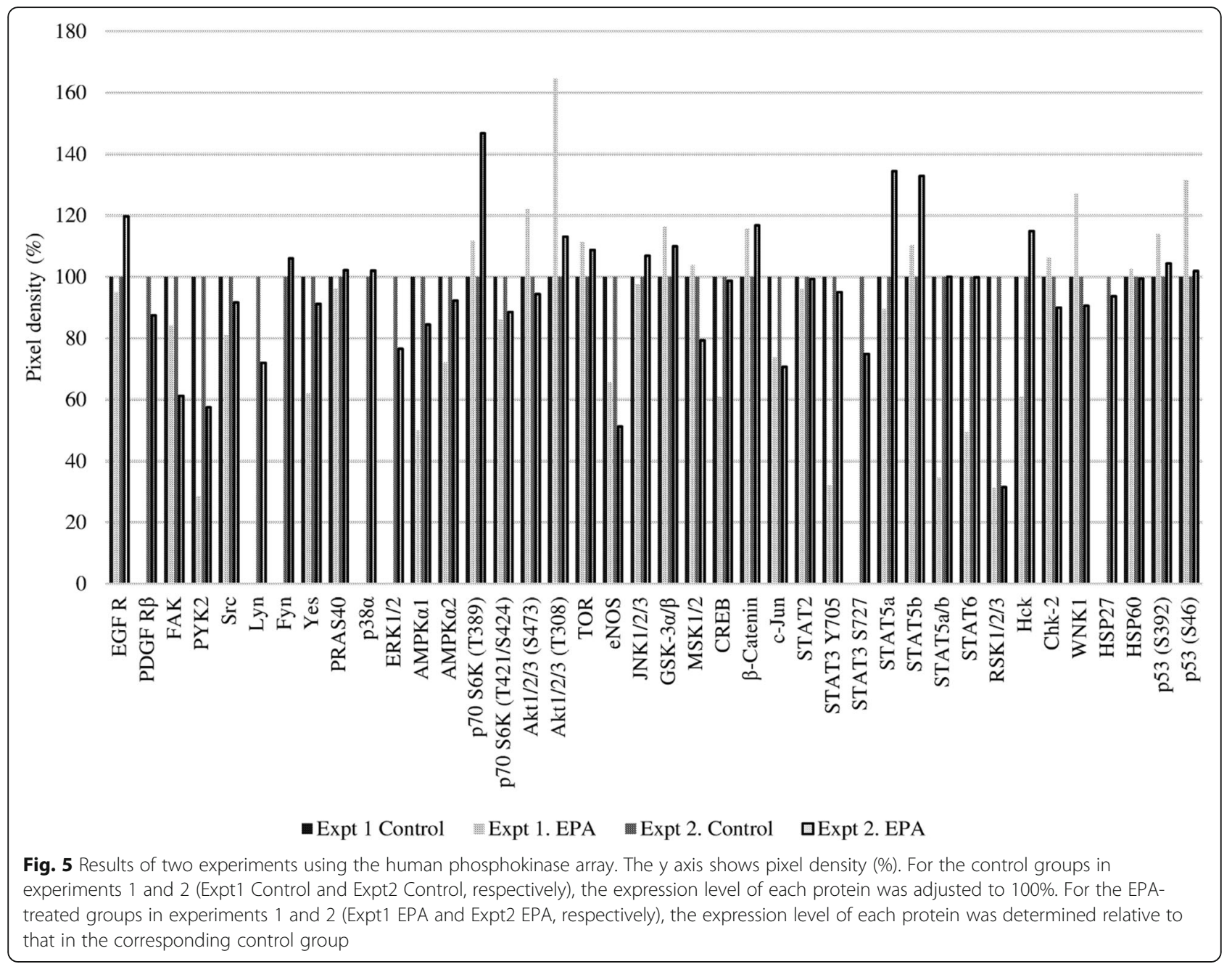

an additional $24 \mathrm{~h}$ before treatment with EPA $(500 \mu \mathrm{M})$ or vehicle as a control. After $2 \mathrm{~h}$ of incubation with EPA or vehicle, samples were prepared for the antibody array according to the manufacturers' protocols. Chemiluminescence detection was performed on a Lumi Cube (Liponics, Tokyo, Japan) using Clarity Western ECL Substrate (Bio-Rad, Hercules, CA, USA). Images of the arrays were analyzed using Image $\mathrm{J}$ software (National Institutes of Health, Bethesda, MD, USA).

\section{Inhibition of ROS production}

PC3 cells were cultured in a $35-\mathrm{mm}$ dish at a density of $3 \times 10^{5}$ cells/dish in DMEM containing 10\% FBS for $24 \mathrm{~h}$, and then washed with PBS and incubated in serum-free DMEM for an additional $24 \mathrm{~h}$. The cells were washed with PBS, and EPA $(500 \mu \mathrm{M})$ with or without $5 \mathrm{mM}$ of NAC (Wako) was added, cells were incubated for $24 \mathrm{~h}$, and cell numbers were counted with a hemocytometer.

\section{Western blot analysis}

PC3 cells were cultured in $60-\mathrm{mm}$ dishes at a density of $8 \times 10^{5}$ cells/dish in $10 \%$ FBS-containing DMEM for $24 \mathrm{~h}$. PC3 cells were cultured with serum starvation for an additional $24 \mathrm{~h}$, then treated with EPA $(500 \mu \mathrm{M})$ or vehicle. The cells were lysed in M-PER (Thermo Fisher Scientific, Waltham, MA, USA) and centrifuged at $13,000 \mathrm{rpm}(30,250 \mathrm{~g})$ at $4{ }^{\circ} \mathrm{C}$ for 10 min. Protein samples were diluted in $2 \times$ Laemmli sample buffer (Bio-Rad), then boiled at $100^{\circ} \mathrm{C}$, and $20 \mu \mathrm{g}$ of protein were loaded in each lane of a TGX precast gel (Bio-Rad) and resolved by electrophoresis $(100 \mathrm{~V}, 0.3 \mathrm{~A})$. The proteins were transferred to an Immun-Blot polyvinylidene difluoride membrane (BioRad) at $100 \mathrm{~V}$ and $0.3 \mathrm{~A}$ for $1 \mathrm{~h}$. The membrane was blocked with Block Ace (KAC, Kyoto, Japan) for $1 \mathrm{~h}$ 
Table 1 Difference in expression levels of various proteins relative to the control in PC3 cells treated with EPA

\begin{tabular}{|c|c|}
\hline Protein & Result \\
\hline sTNF-R2 & $-^{+}$ \\
\hline SMAC & $+^{2}$ \\
\hline Survivin & + \\
\hline TRAIL-R1 & + \\
\hline Caspase 8 & + \\
\hline Bcl-2 & - \\
\hline p53 & + \\
\hline
\end{tabular}

1,2. Differences relative to the control are shown as $\pm>$ $20 \%$.

1, 2. Differences relative to the control are shown as $\pm>20 \%$

and probed with antibody solution for $1 \mathrm{~h}$ at room temperature. The membrane was washed with Trisbuffered saline (Bio-Rad) containing 1\% Tween 20. Lumi Cube and Clarity Western ECL substrate were used for signal detection, and protein band intensity was analyzed using Image J software.

\section{Statistical analysis}

Statistical analyses were performed using $\mathrm{R}$ v.3.4.3 (https://www.r-project.org/). Data are presented as means \pm standard error, and differences between means were evaluated with Dunnett's test. A $P$ value less than 0.05 was considered statistically significant.

\section{Results}

\section{EPA suppresses $\mathrm{PC} 3$ cell proliferation}

EPA inhibited the proliferation of PC3 cells in a dosedependent manner (Fig. 1). However, only the highest concentration of EPA $(500 \mu \mathrm{M})$ significantly reduced the number of cells to $50 \%$ of the control value.

In serum-free medium, the number of PC3 cells in the control group did not change over a 24-h period, but gradually decreased with EPA treatment, with significant differences detected after $3 \mathrm{~h}$. After $12 \mathrm{~h}$, the number of cells was $50 \%$ of the control value and remained constant up to $24 \mathrm{~h}$ (Fig. 2).
Table 2 Differences in the expression levels of various proteins in EPA-treated PC3 cells relative to the control (related to Fig. 5)

\begin{tabular}{|c|c|c|}
\hline Protein & Expt 1. & Expt 2. \\
\hline FAK & $---^{2}$ & $---{ }^{\prime}$ \\
\hline PYK2 & -ーーー & -ーーー \\
\hline $\mathrm{Src}$ & -ーー- & $--^{3}$ \\
\hline Yes & ---- & -- \\
\hline AMPK $a 1$ & -ー-ー & --- \\
\hline $\mathrm{AMPK} \propto 2$ & -ーー- & -- \\
\hline p70 S6K (T389) & $+++^{2}$ & $++++^{1}$ \\
\hline p70 S6K (T421/S424) & -ー- & -一- \\
\hline Akt $1 / 2 / 3(\mathrm{~T} 308)$ & ++++ & +++ \\
\hline TOR & +++ & $+t^{3}$ \\
\hline eNOS & ---- & -ー-ー \\
\hline GSK- $3 \alpha / \beta$ & +++ & ++ \\
\hline$\beta$-Catenin & +++ & +++ \\
\hline c-Jun & -ーーー & -ー-ー \\
\hline STAT5b & +++ & ++++ \\
\hline $\mathrm{RSK} 1 / 2 / 3$ & -ーーー & -ーーー \\
\hline
\end{tabular}

1. Differences relative to the control are shown as $\pm \pm \pm \pm>20 \%$.

2. Differences relative to the control are shown as $\pm \pm \pm>10 \%$.

3. Differences relative to the control are shown as $\pm \pm>5 \%$.

1. Differences relative to the control are shown as $\pm \pm \pm \pm>20 \%$

2. Differences relative to the control are shown as $\pm \pm \pm>10 \%$

3. Differences relative to the control are shown as $\pm \pm>5 \%$

\section{EPA inhibits PC3 cell migration and invasion}

EPA inhibited both PC3 cell migration and invasion in a dose-dependent manner, and the rate of migration and invasion relative to the control was $43 \%$ (Fig. 3a) and 26\% (Fig. 3b), respectively, at $200 \mu \mathrm{mol} / \mathrm{L}$ EPA. Thus, PC3 cell invasion was inhibited to a greater extent than migration by EPA.

\section{Proteins associated with phosphokinase and apoptosis pathways are activated by EPA treatment}

Using two types of antibody arrays, we determined that proteins involved in the phosphokinase and apoptosis pathways were activated by EPA treatment. Based on the results shown in Fig. 2, protein samples for antibody arrays and western blotting were prepared $2 \mathrm{~h}$ after adding $500 \mu \mathrm{mol} / \mathrm{L}$ EPA. More significant results were obtained between the EPA-treated and untreated 


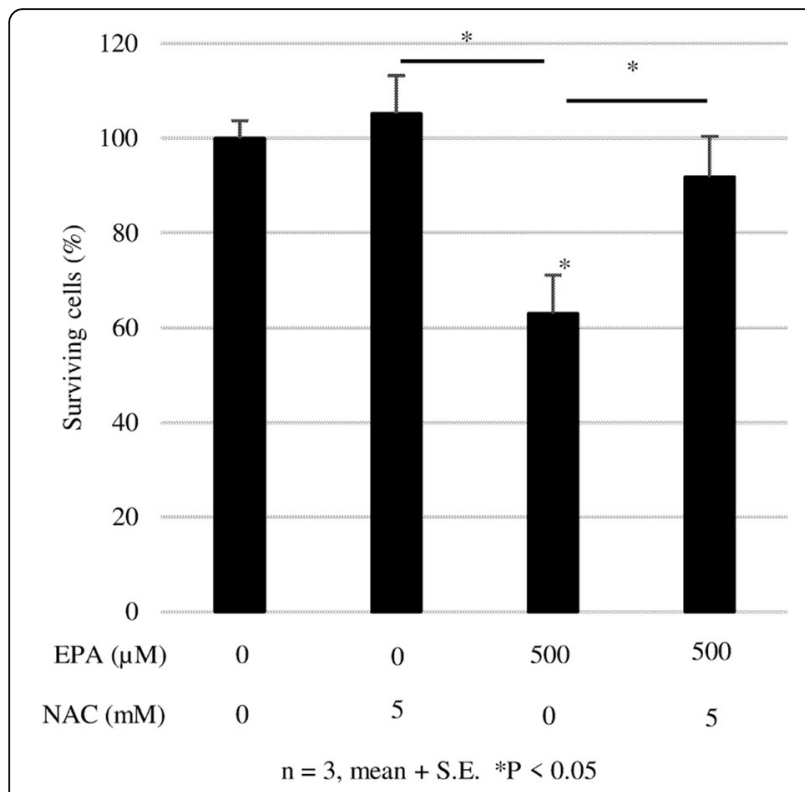

Fig. 6 Effect of NAC on the anti-cancer effect of EPA against PC3 cells. After $24 \mathrm{~h}$ of culture in serum-free medium, cells were treated with EPA $(500 \mu \mathrm{M})$ or NAC or both. Data represent mean + SEM $(n=3) .{ }^{*} P<0.05$

control groups using the phosphokinase as compared to the apoptosis array (Figs. 4 and 5). The expression of apoptosis-related proteins including soluble tumor necrosis factor receptor (sTNF-R)2, second mitochondriaderived activators of caspase (SMAC), Survivin, tumor necrosis factor related apoptosis-inducing ligand receptor (TRAIL-R)1, caspase 8, B-cell lymphoma (Bcl)-2, and p53 differed by more than $20 \%$ between the two groups (Table 1), with sTNF-R2 and Bcl-2 being downregulated and the other proteins being upregulated by EPA treatment.

The phosphokinase array data showed increased or decreased phosphorylation of several kinases (Fig. 5 and Table 2). EPA reduced the phosphorylation of several proteins by over $20 \%$ relative to the control, including Pyk2, endothelial nitric oxide synthase (eNOS), c-Jun, and ribosomal S6 kinases (RSK)1/2/3.

\section{Contribution of ROS to PC3 cell death}

We next analyzed the contribution of ROS to the effects of EPA on PC3 cell survival and found that EPA treatment decreased survival to $60 \%$ of the control rate, whereas NAC ( $5 \mathrm{mmol} / \mathrm{L})$ had no effect. Treatment with both EPA and NAC restored the survival rate to the control level. Thus, NAC abrogates the anti-cancer effect of EPA against PC3 cells (Fig. 6).

\section{EPA inhibits ERK and Pyk2 phosphorylation}

To confirm the mechanism of action of EPA, cells were treated at a concentration of $500 \mu \mathrm{mol} / \mathrm{L}$, and the expression of native and phosphorylated ERK and Pyk2 was examined by western blotting. EPA significantly suppressed ERK phosphorylation at 1 and $2 \mathrm{~h}$, although there was no difference relative to the control group after $3 \mathrm{~h}$ (Fig. 7). A similar significant inhibitory effect was observed on Pyk2 phosphorylation at 2 and $4 \mathrm{~h}$ (Fig. 8). Treatment with the ROS inhibitor NAC (5 mM) alone did not affect Pyk2 phosphorylation, while NAC slightly enhanced the inhibitory effect of EPA on Pyk2 phosphorylation (Fig. 9).

\section{Discussion}

The anti-cancer effects of n-3 PUFAs in vitro and in vivo are well known $[13,14,18,26-31]$, and these effects have been observed in PC cells. Our previous study showed that the n-3 PUFAs EPA and DHA inhibit PC3 cell proliferation, migration, and invasion [18]. Several reports have indicated that n-3 PUFAsinduced apoptosis or oxidative stress suppresses the growth of various types of cancer cells, including PC cells [32, 33]. Activation of NRTKs may be related to PC cell growth, and clinical trials of therapeutics that target NRTK are currently underway [34, 35]. Other mechanisms of action have been proposed for the anti-cancer effects of n-3 PUFAs [36, 37]. In this study, we addressed this question using phosphokinase and apoptosis antibody arrays and examined the contribution of ROS to the anti-cancer effect of EPA on PC3 cells.

For the antibody array analysis, the cell cycle of PC3 cells was synchronized by culturing in serum-free medium for $24 \mathrm{~h}$. PC3 cells are relatively resistant to the anti-cancer effects of EPA. We treated cells with a moderately high concentration of EPA that was nonetheless within the physiological range $(500 \mu \mathrm{M})$. PC3 cell proliferation did not change over $24 \mathrm{~h}$ in the control group, which is consistent with the notion that the rates of proliferation and death are equivalent in PC3 cells grown under conditions of moderate nutrient starvation. In contrast, the number of cells in the EPA-treated group decreased over time, with significant differences relative to the control group observed from $3 \mathrm{~h}$ to $24 \mathrm{~h}$.

The results of the apoptosis array showed that EPA increased the expression of the pro-apoptotic proteins TRAIL-R1, caspase 8 , and p53, and decreased that of the anti-apoptotic protein Bcl-2. However, EPA also increased the levels of the anti-apoptotic proteins SMAC and Survivin while having no effect on caspase 3. We speculated that ROS induced cell death via a pathway independent of caspase-induced apoptosis. 


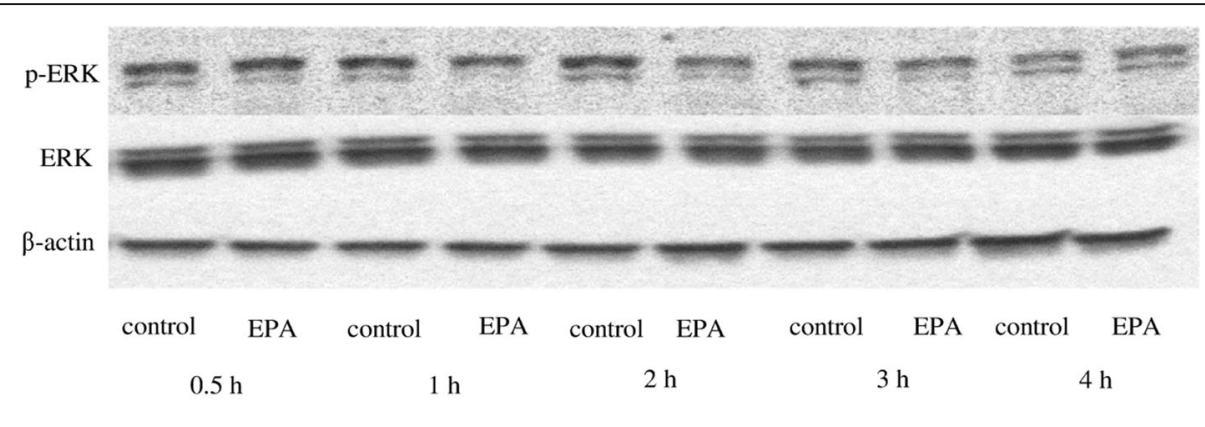

160

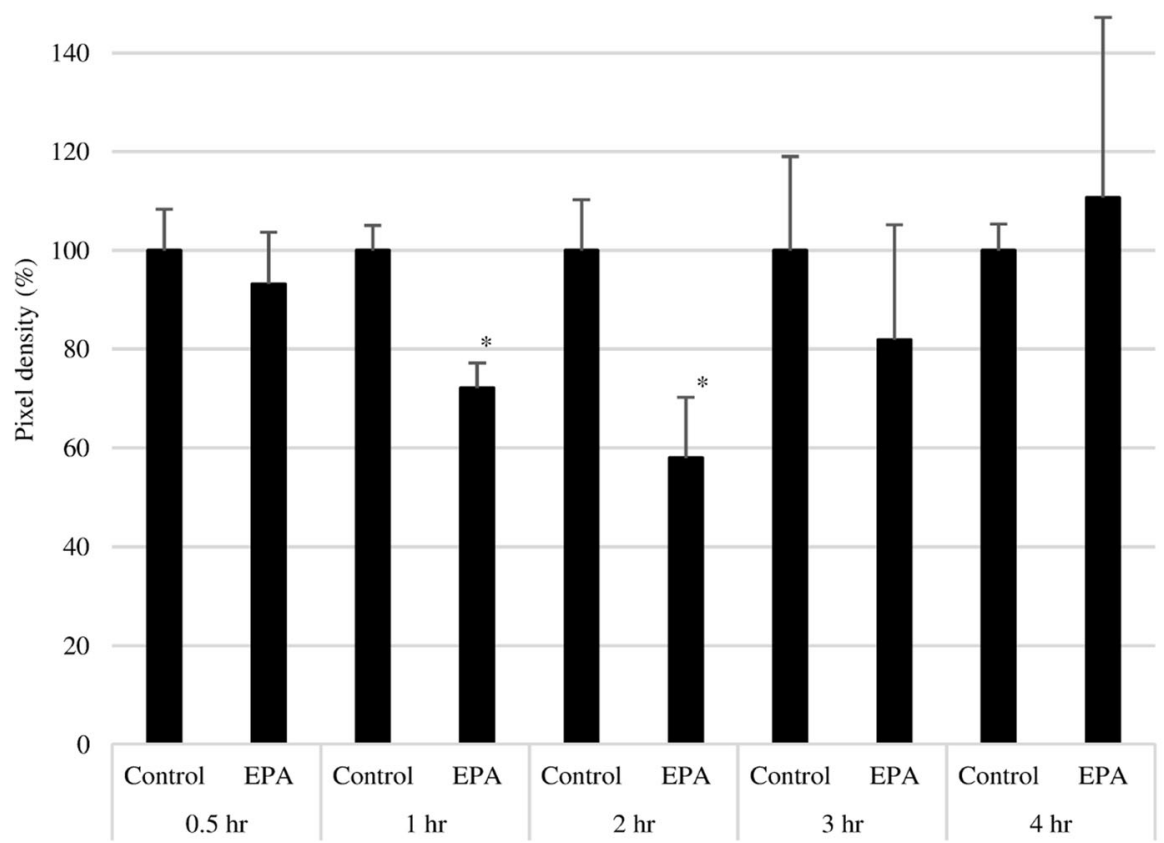

Fig. 7 Effect of EPA on ERK1/2 phosphorylation. Upper panel: Representative results of western blot analysis. Lower panel: Pixel density of the control group at the indicated times was adjust to 100\%; relative pixel density of EPA-treated PC3 cells is shown. Data represent mean + SEM $(n=3) .{ }^{*} P<0.05$

To test this hypothesis, we evaluated the effect of the ROS inhibitor NAC on EPA-treated cells. First, we measured ROS generation at two time points, 2 and $24 \mathrm{~h}$. In these experiments, we observed relevant (not significant) ROS generation induced by EPA only at $2 \mathrm{~h}$, and NAC reduced the ROS level to the control (data not shown). We observed that the addition of NAC abrogated the anti-cancer effects of EPA (Fig. 6), suggesting that ROS induced by EPA suppressed PC3 cell proliferation. This is supported by previous reports showing that the anti-cancer effects of $n-3$ PUFAs are mediated by ROS in liver cancer and PC cells [23, 24].

We also investigated the contribution of cell proliferation pathways to the anti-cancer effects of EPA using a phosphokinase antibody array. The results showed that Pyk2, eNOS, c-Jun, and RSK1/2/3 were downregulated by over $20 \%$ by EPA treatment as compared to the control group. Western blot analysis revealed that ERK and Pyk2 phosphorylation were inhibited by EPA (Figs. 7 and 8). Suppressing ROS production with NAC did not affect the inhibitory effects of EPA on Pyk2 phosphorylation, suggesting that the suppression of Pyk2 phosphorylation by EPA does not involve modulation of ROS. Pyk2 is a member of the focal adhesion kinase (FAK) family of NRTK and plays important roles in cell survival, proliferation, and migration [38-41]. In our experiments, FAK phosphorylation was also suppressed by EPA treatment (Table 2). FAK is localized at the site of cell adhesion with the extracellular matrix along with integrins, whereas Pyk2 associates with integrin within 


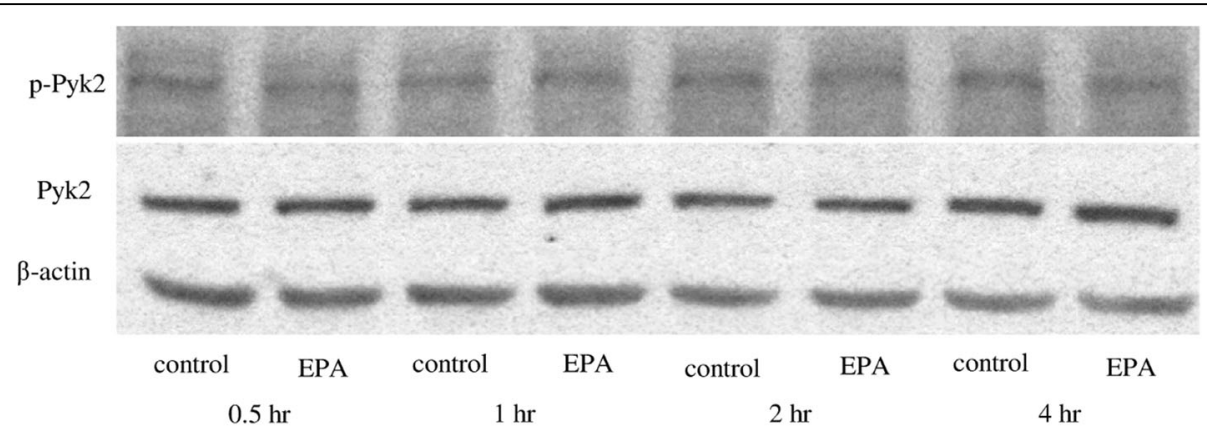

120

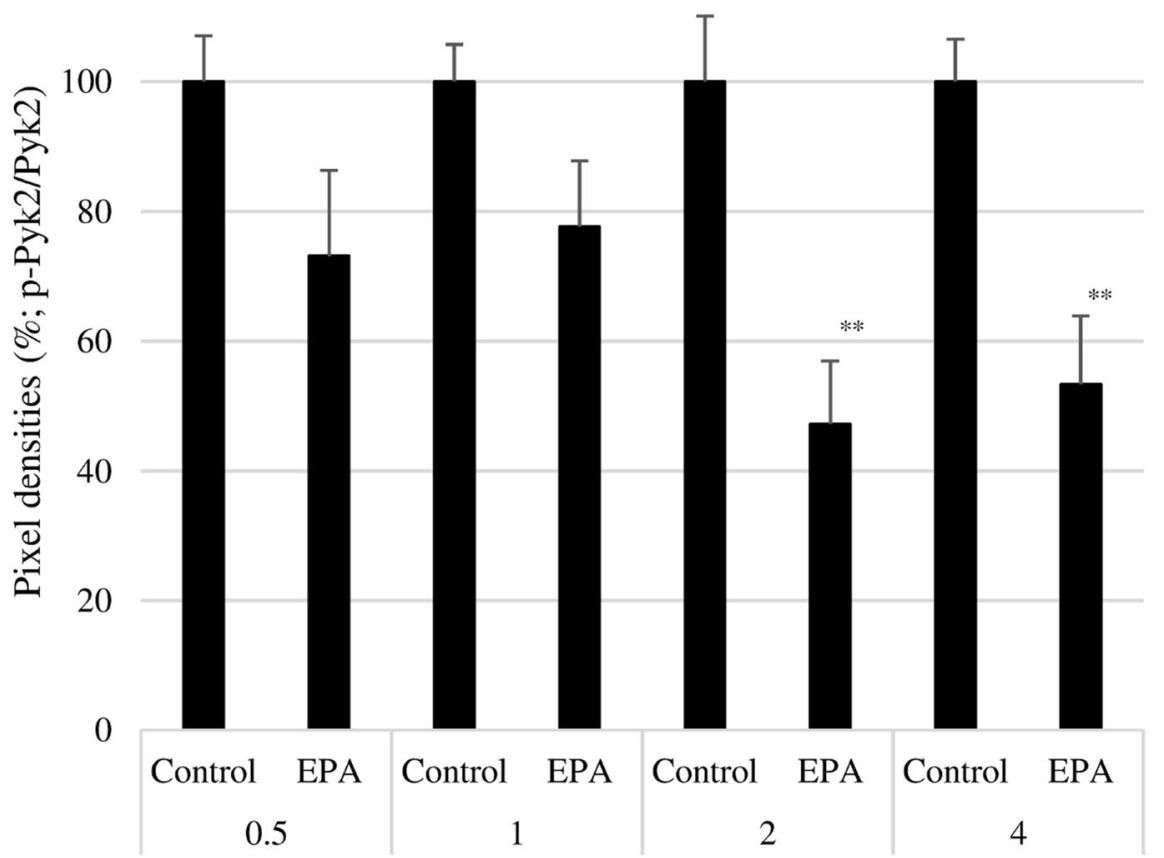

Fig. 8 Effect of EPA on Pyk2 phosphorylation. Upper panel: Representative result of western blot analysis. Lower panel: Pixel density of the control group at the indicated times was adjusted to $100 \%$; relative pixel density of EPA-treated PC3 cells is shown. Data represent mean + SEM $(n=3) .{ }^{*} P<0.05$

the cell $[42,43]$. Since several types of integrins are expressed in PC3 cells and interact with extracellular matrix, inhibition of activated FAK at these sites may prevent cell adhesion and migration [44]. The Nterminal domain of FAK has phosphorylation sites for the cell proliferation-related factors epidermal growth factor receptor, c-Met, and Src [45]. The antibody used in the antibody array detected phosphorylated tyrosine 402 of Pyk2, which is necessary for Src activation [40] and was slightly reduced in our experiment (Table 2). It was reported that Pyk2 activation induced smooth muscle contraction by activating Rho-associated kinase signaling [46], and FAK and Pyk2 show similar activities on this pathway in the regulation of cell migration [38, 47, 48]. Activation of both factors leads to abnormalities in cell morphology and movement associated with malignant transformation. Our results suggest that EPA negatively regulates the proliferation, migration, and invasion of PC3 cells via inhibition of Pyk2 and FAK [18].

Pyk2 is an NRTK that is activated by increased intracellular $\mathrm{Ca}^{2+}$ concentrations $[49,50]$, which are in turn increased by n-3 PUFAs and ROS [23, 51-53]. In our results, the n-3 PUFA EPA inhibited Pyk2 phosphorylation, whereas ROS inhibition by NAC did not affect the inhibitory effects of EPA, suggesting that EPA blocks Pyk2 activation independent of intracellular $\mathrm{Ca}^{2+}$ levels. 


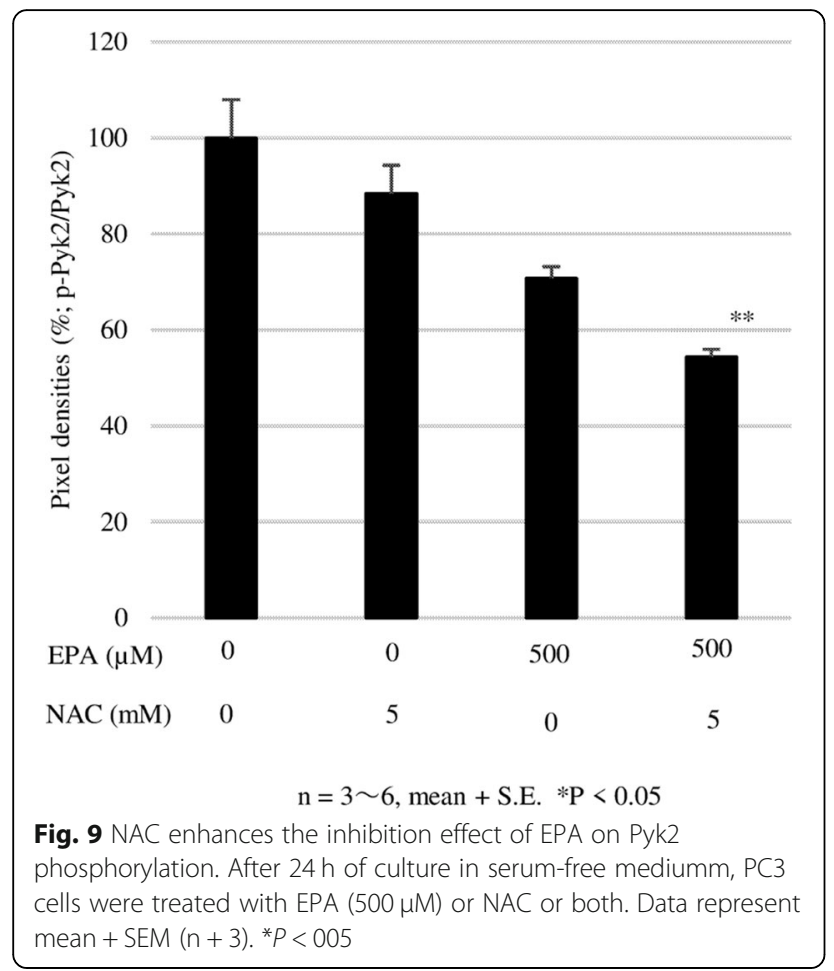

\section{Conclusions}

Our results demonstrate that EPA induced cell death by stimulating ROS production in PC3 cells, and suppressed Pyk2 phosphorylation inducing inhibition of cell proliferation, migration, and invasion partly controlled by downstream Pyk2 signaling. Our findings were summarized in Fig. 10. These results provide a basis for the development of novel therapeutics for the treatment of PC.

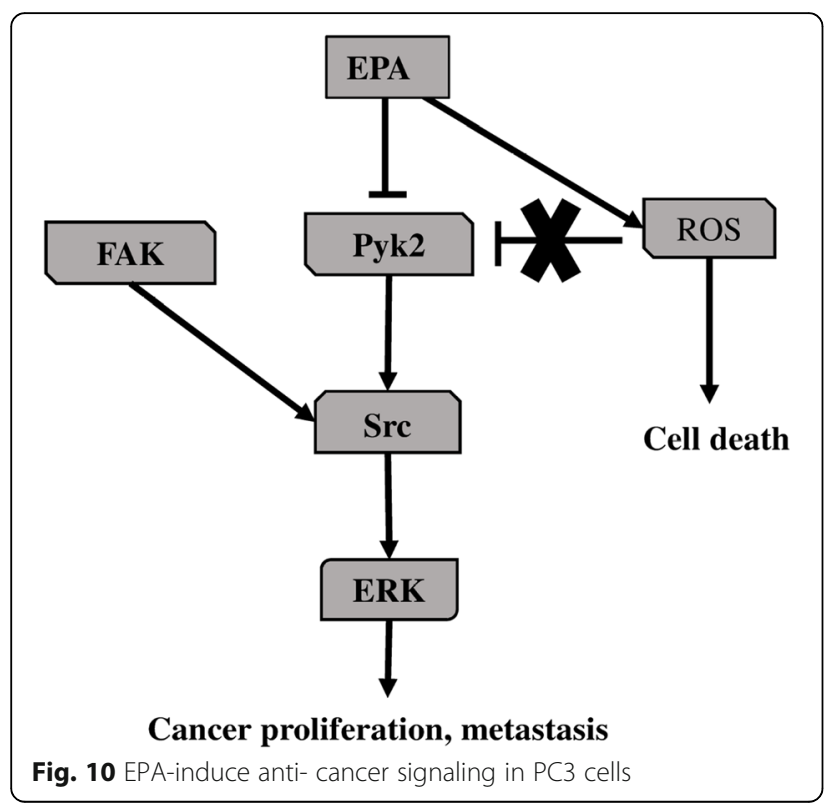

\section{Abbreviations}

ADT: Androgen deprivation therapy; Bcl-2: B-cell lymphoma 2;

CRPC: Castration-resistant prostate cancer; DHA: Docosahexaenoic acid; eNOS: Endothelial nitric oxide synthase; EPA: Eicosapentaenoic acid;

ERK: Extracellular signal-regulated kinase; FAK: Focal adhesion kinase; n-3 PUFA: n-3 polyunsaturated fatty acid; NAC: N-acetyl cysteine; NRTK: Nonreceptor tyrosine kinase; PBS: Phosphate-buffered saline; PC: Prostate cancer; Pyk2: Proline-rich tyrosine kinase-2; ROS: Reactive oxygen species; RSK1/2/ 3: Ribosomal S6 kinase 1/2/3; RTK: Receptor tyrosine kinase; SMAC: Second mitochondria-derived activators of caspase; sTNF-R2: Soluble tumor necrosis factor receptor 2; TRAIL-R1: Tumor necrosis factor-related apoptosis-inducing ligand and receptor 1

\section{Acknowledgments}

We would like to thank FORTE (https://www.forte-science.co.jp/) for their language review of the manuscript.

\section{Adherence to national and international regulations Not applicable.}

\section{Authors' contributions}

$\mathrm{KO}$ conceived and designed the study. KO performed the experiments. SS performed several experiments according to the reviewer's comments. KO, $\mathrm{CW}$ and $\mathrm{KK}$ wrote the paper. $\mathrm{KO}, \mathrm{TS}, \mathrm{KO}$ and SS designed the figures and tables. KO, CW, TS and KK reviewed and edited the manuscript. All authors read and approved the manuscript and agree to be accountable for all aspects of the research in ensuring that the accuracy or integrity of any part of the work are appropriately investigated and resolved.

\section{Funding}

This work was partly supported by JSPS KAKENHI (Grant Number: JP26350904).

\section{Availability of data and materials \\ Available.}

Ethics approval and consent to participate

Not applicable.

\section{Consent for publication}

Not applicable.

\section{Competing interests}

The authors declare that they have no competing interests.

\section{Author details}

${ }^{1}$ Laboratory of Physiology, Faculty of Pharmaceutical Sciences, Josai University, 1-1 Keyakidai, Sakado, Saitama 350-0295, Japan. ${ }^{2}$ Laboratory of Clinical Pathology, Faculty of Pharmaceutical Sciences, Josai University, 1-1 Keyakidai, Sakado, Saitama 350-0295, Japan.

Received: 14 May 2019 Accepted: 30 September 2019

Published online: 31 January 2020

\section{References}

1. Global Burden of Disease Cancer Collaboration, Fitzmaurice C, Akinyemiju TF, Al Lami FH, Alam T, Alizadeh-Navaei R, Allen C, Alsharif U, Alvis-Guzman $\mathrm{N}$, Amini $\mathrm{E}$, et al. Global, regional, and national cancer incidence, mortality, years of life lost, years lived with disability, and disability-adjusted life-years for 29 cancer groups, 1990 to 2016: a systematic analysis for the global burden of disease study. JAMA Oncol. 2018;4(11):1553-68.

2. Kimura T, Egawa S. Epidemiology of prostate cancer in Asian countries. Int J Urol. 2018;25(6):524-31.

3. Ritch C, Cookson M. Recent trends in the management of advanced prostate cancer. F1000Res. 2018;21:7.

4. Small EJ, Srinivas S. The antiandrogen withdrawal syndrome. Experience in a large cohort of unselected patients with advanced prostate cancer. Cancer. 1995;76(8):1428-34.

5. Hurwitz MD. Chemotherapy and radiation for prostate cancer. Transl Androl Urol. 2018;7(3):390-8. 
6. Hussain M, Fizazi K, Saad F, Rathenborg P, Shore N, Ferreia U, Ivashchenko P, Demirthan E, Modelska K, Phung D, et al. Enzalutamide in men with nonmetastatic, castration-resistant prostate cancer. N Engl J Med. 2018; 378(26):2465-74.

7. Balk EM, Lichtenstein AH. Omega-3 fatty acids and cardiovascular disease: summary of the 2016 agency of healthcare research and quality evidence review. Nutrients. 2017;9(8). https://doi.org/10.3390/nu9080865.

8. Harris WS. Fish oils and plasma lipid and lipoprotein metabolism in humans: a critical review. J Lipid Res. 1989;30(6):785-807.

9. Takenouchi Y, Ohtake K, Nobe K, Kasono K. Eicosapentaenoic acid ethyl ester improves endothelial dysfunction in type 2 diabetic mice. Lipids Health Dis. 2018;17(1):118.

10. Serini S, Calviello G. Modulation of Ras/ERK and phosphoinositide signaling by long-chain n-3 PUFA in breast cancer and their potential complementary role in combination with targeted drugs. Nutrients. 2017;9(3). https://doi. org/10.3390/nu9030185.

11. Sawada N, Inoue M, Iwasaki M, Sasazuki S, Shimazu T, Yamaji T, Takachi R, Tanaka Y, Mizokami M, Tsugane S, et al. Consumption of n-3 fatty acids and fish reduces risk of hepatocellular carcinoma. Gastroenterology. 2012;142(7): 1468-75.

12. Hidaka A, Shimazu T, Sawada N, Yamaji T, Iwasaki M, Sasazuki S, Inoue M, Tsugane S. Japan public health center-based prospective study group. Fish, n-3 PUFA consumption, and pancreatic cancer risk in Japanese: a large, population-based, prospective cohort study. Am J Clin Nutr. 2015;102(6): 1490-7.

13. Das UN. Tumoricidal action of cis-unsaturated fatty acids and their relationship to free radicals and lipid peroxidation. Cancer Lett. 1991;56(3): 235-43.

14. Bégin ME, Das UN, Ells G, Horrobin DF. Selective killing of human cancer cells by polyunsaturated fatty acids. Prostaglandins Leukot Med. 1985;19(2): 177-86.

15. Das UN, Begin ME, Ells G, Huang YS, Horrobin DF. Polyunsaturated fatty acids augment free radical generation in tumor cells in vitro. Biochem Biophys Res Commun. 1987;145(1):15-24.

16. Das UN, Huang YS, Begin ME, Ells G, Horrobin DF. Uptake and distribution of cis-unsaturated fatty acids and their effect on free radical generation in normal and tumor cells in vitro. Free Radic Biol Med. 1987;3(1):9-14.

17. MacLean CH, Newberry SJ, Mojica WA, Khanna P, Issa AM, Suttorp MJ, Lim YW, Traina SB, Hilton L, Garland R, et al. Effects of omega-3 fatty acids on cancer risk: a systematic review. JAMA. 2006;295(4):403-15.

18. Oono K, Takahashi K, Sukehara S, Kurosawa H, Matsumura T, Taniguchi S, Ohta S. Inhibition of PC3 human prostate cancer cell proliferation, invasion and migration by eicosapentaenoic acid and docosahexaenoic acid. Mol Clin Oncol. 2017;7(2):217-20.

19. Chang YM, Kung HJ, Evans CP. Nonreceptor tyrosine kinases in prostate cancer. Neoplasia. 2007;9(2):90-100.

20. Watson RW, Fitzpatrick JM. Targeting apoptosis in prostate cancer: focus on caspases and inhibitors of apoptosis proteins. BJU Int. 2005;96(Suppl 2):30-4

21. Moloney JN, Cotter TG. ROS signaling in the biology of cancer. Semin Cell Dev Biol. 2018;80:50-64.

22. Thannickal VJ, Fanburg BL. Reactive oxygen species in cell signaling. Am J Physiol Lung Cell Mol Physiol. 2000;279(6):1005-28.

23. Zhang Y, Han L, Qi W, Cheng D, Ma X, Hou L, Cao X, Wang C. Eicosapentaenoic acid (EPA) induced apoptosis in HepG2 cells through ROS-Ca ${ }^{2+}-J N K$ mitochondrial pathways. Biochem Biophys Res Commun. 2015;456(4):926-32.

24. Ding Y, Ren K, Dong H, Song F, Chen J, Guo Y, Liu Y, Tao W, Zhang Y. Flavonoids from persimmon (Diospyros kaki L.) leaves inhibit proliferation and induce apoptosis in PC-3 cells by activation of oxidative stress and mitochondrial apoptosis. Chem Biol Interact. 2017;275:210-7.

25. Shin S, Jing K, Jeong S, Kim N, Song KS, Heo JY, Park JH, Seo KS, Han J, Park $J$, et al. The omega-3 polyunsaturated fatty acid DHA induces simultaneous apoptosis and autophagy via mitochondrial ROS-mediated Akt-mTOR signaling in prostate cancer cells expressing mutant p53. Biomed Res Int. 2013;2013:568671.

26. Bégin ME, Ells G, Das UN, Horrobin DF. Differential killing of human carcinoma cells supplemented with n-3 and n-6 polyunsaturated fatty acids. J Natl Cancer Inst. 1986;77(5):1053-62.

27. Corsetto PA, Montorfano G, Zava S, Jovenitti IE, Cremona A, Berra B, Rizzo AM. Effects of n-3 PUFAs on breast cancer cells through their incorporation in plasma membrane. Lipids Health Dis. 2011;10:73-89.
28. McEntee MF, Ziegler C, Reel D, Tomer K, Shoieb A, Ray M, Li X, Neilsen N, Lih FB, O'Rourke D, et al. Dietary n-3 polyunsaturated fatty acids enhance hormone ablation therapy in androgen therapy in androgen-dependent prostate cancer. Am J Pathol. 2008;173(1):229-41.

29. Altenburg JD, Siddiqui RA. Omega-3 polyunsaturated fatty acids downmodulate CXCR4 expression and function in MDA-MB-231 breast cancer cells. Mol Cancer Res. 2009;7(7):1013-20.

30. Berquin IM, Edwards IJ, Chen YQ. Multi-targeted therapy of cancer by omega-3 fatty acids. Cancer Lett. 2008;269(2):363-77.

31. Davidson LA, Nguyen DV, Hokanson RM, Callaway ES, Isett RB, Turner ND, Dougherty ER, Wang N, Lupton JR, Carroll RJ, et al. Chemopreventive n-3 polyunsaturated fatty acids reprogram genetic signatures during colon cancer initiation and progression in the rat. Cancer Res. 2004;64(18):6797-804.

32. Song EA, Kim H. Docosahexaenoic acid induces oxidative DNA damage and apoptosis, and enhances the chemosensitivity of cancer cells. Int J Mol Sci. 2016;17(8). https://doi.org/10.3390/ijms17081257.

33. Camargo CQ, Brunetta HS, Nunes EA. Effects of cotreatment with omega-3 polyunsaturated fatty acids and anticancer agents on oxidative stress parameters: a systematic review of in vitro, animal, and human studies. Nutr Rev. 2018;76(10):765-77.

34. Arora A, Scholar EM. Role of tyrosine kinase inhibitors in cancer therapy. J Pharmacol Exp Ther. 2005;315(3):971-9.

35. Araujo JC, Trudel GC, Saad F, Armstrong AJ, Yu EY, Bellmunt J, Wilding G, McCaffrey J, Serrano SV, Matveev VB, et al. Docetaxel and dasatinib or placebo in men with metastatic castration-resistant prostate cancer (READY): a randomized, double-blind phase 3 trial. Lancet Oncol. 2013; 14(13):1307-16.

36. D'Eliseo D, Velotti F. Omega-3 fatty acids and cancer cell cytotoxicity: implications for multi-targeted cancer therapy. J Clin Med. 2016;5(2). https:// doi.org/10.3390/jem5020015.

37. Menedez JA, Lupu R. Fatty acid synthase and the lipogenetic phenotype in cancer pathogenesis. Nat Rev Cancer. 2007;7(10):763-77.

38. Avraham H, Park SY, Schinkmann K, Avraham S. RAFTK/Pyk2-mediated cellular signaling. Call Signal. 2000;12(3):123-33.

39. Sun CK, Man K, Ng KT, Ho JW, Lim ZX, Cheng Q, Lo CM, Poon RT, Fan ST. Proline-rich tyrosine kinase 2 (Pyk2) promotes proliferation and invasiveness of hepatocellular carcinoma cells through c-Src/ERK activation. Carcinogenesis. 2008;29(11):2096-105.

40. Zhao M, Finlay D, Zharkikh I, Vuori K. Novel role of Src in priming Pyk2 phosphorylation. PLoS One. 2016;11(2):e0149231.

41. Perez J, Torres RA, Rocic P, Cismowski MJ, Weber DS, Darley-Usmar VM, Lucchesi PA. PYK2 signaling is required for PDGF-dependent vascular smooth muscle cell proliferation. Am J Physiol Cell Physiol. 2011;301(1): C242-51.

42. Matsuya M, Sasaki H, Aoto H, Mitaka T, Nagura K, Ohba T, Ishino M, Takahashi S, Suzuki R, Sasaki T. Cell adhesion kinase beta forms a complex with a new member, hic-, of proteins localized at focal adhesions. J Biol Chem. 1998;273(2):1003-14.

43. Murphy JM, Park H, Lim STS. FAK and Pyk2 in disease. Front Biol. 2016; 11(1):1-9.

44. Juan-Rivera MC, Martinez-Ferrer M. Integrin inhibitors in prostate cancer Cancers (Basel). 2018;10(2). https://doi.org/10.3390/cancers10020044.

45. Lee BY, Trimpson P, Horvath LG, Daly RJ. FAK signaling in human cancer as a target for therapeutics. Pharmacol Ther. 2015;146:132-49.

46. Mills RD, Mita M, Walsh MP. A role for the $\mathrm{Ca}^{2+}$-dependent tyrosine kinase Pyk2 in tonic depolarization-induced vascular smooth muscle contraction. J Muscle Res Cell Motil. 2015;36(6):479-89.

47. Miller NL, Kleinschmidt EG, Schlaepfer DD. Rho GEFs in cell motility: novel links between Rgnef and focal adhesion kinase. Curr Mol Med. 2014;14(2): 221-34.

48. Tornin J, Hermida-Prado F, Padda RS, Gonzalez MV, Alvarez-Fernandez C, Rey V, Martinez-Cruzado L, Estuinan O, Menendez ST, Fernandez-Nevado L, et al. FUS-CHOP promotes invasion in myxoid liposarcoma through a SRC/ FAKRHO/ROCK-dependent pathway. Neoplasia. 2018;20(1):44-56.

49. Rozengurt E. Mitogenic signaling pathways induced by $\mathrm{G}$ protein-coupled receptors. J Cell Physiol. 2007;213(3):589-602.

50. Hirschler-Laszkiewica I, Chen SJ, Bao L, Wang J, Zhang XQ, Shanmughapriya S, Keefer K, Madesh M, Cheung JY, Miller BA. The human ion channel TRPM2 modulates neuroblastoma cell survival and mitochondrial function through Pyk2, CREB, and MCU activation. Am J Physiol Cell Physiol. 2018; 315(4):C571-86 
51. Jakobsen CH, Størvold GL, Bremseth H, Follestad T, Sand K, Mack M, Olsen $\mathrm{KS}$, Lundemo AG, Iversen JG, Krokan HE, et al. DHA induces ER stress and growth arrest in human colon cancer cells: associations with cholesterol and calcium homeostasis. J Lipid Res. 2008;49(10):2089-100.

52. Hempel N, Trebak M. Crosstalk between calcium and reactive oxygen species signaling in cancer. Cell Calcium. 2017;63:70-96.

53. Yamamoto S, Shimazu S, Kiyonaka S, Takahashi N, Wajima T, Hara Y, Negoro T, Hiroi T, Kiuchi Y, Okada T, et al. TRPM2-mediated $\mathrm{Ca}^{2+}$ influx induces chemokine production in monocytes that aggravates inflammatory neutrophil infiltration. Nat Med. 2008;14(7):738.

\section{Publisher's Note}

Springer Nature remains neutral with regard to jurisdictional claims in published maps and institutional affiliations.

Ready to submit your research? Choose BMC and benefit from:

- fast, convenient online submission

- thorough peer review by experienced researchers in your field

- rapid publication on acceptance

- support for research data, including large and complex data types

- gold Open Access which fosters wider collaboration and increased citations

- maximum visibility for your research: over $100 \mathrm{M}$ website views per year

At $\mathrm{BMC}$, research is always in progress.

Learn more biomedcentral.com/submissions 